\title{
JAIME ARÔXA: UM ESTUSIASTA DA DANÇA
}

\author{
Entrevista realizada com o Prof. de Dança de Salão Jaime Arôxa
}

Entrevistadoras: Roberta Miranda Ferreira, Universidade Federal do Triângulo Mineiro UFTM, Uberaba, Minas Gerais - Brasil

Michele Viviene Carbinato, Universidade de São Paulo - USP, São Paulo - Brasil

\section{RESUMO}

O professor de dança de salão Jaime Arôxa é um dos mais renomados do Brasil. Sua companhia de dança se destaca na formação inicial e continuada de professores na área e em coreografias que são divulgadas na mídia televisiva, peças de teatros e filmes. A leitura sobre a percepção do entrevistado sobre a dança e o seu processo de ensino pode instigar a reflexão sobre a natureza da dança e seu viés artístico. Acreditamos também que a atenção dada ao ensino focado no aluno, pode ser um dos indícios do sucesso da Cia tanto nacional, quanto internacionalmente.

Palavras-Chave: Dança; Ensino; Arte.

\section{JAIME ARÔXA: A ENTUSIASTA THE DANCE}

\begin{abstract}
The master of dance in ballroom Jaime Arôxa is one of the most renowned from Brazil. His dance company drafts in initial and continuing teacher education in the area and theirs choreographies that are reveal through television, films and theater. The reading on the interviewees' perception of the dance and its teaching process can instigate reflection on the nature of dance and his artistic bias. We also believe that the attention given to teaching focuses on the student, may be one index of the success of the company both national, and internationally.
\end{abstract}

Key-Word: Dancing; Teaching; Art.

\section{JAIME ARÔXA: A ENTUSIASTA LA DANZA}

\section{RESUMÉN}

El maestro de baile de salón Jaime Arôxa es uno de los más reconocidos de Brasil. Su compañía de danza sobresale en la formación inicial y permanente del profesorado en el área y en las coreografías que son visualizados a través de la televisión, películas y teatro. La lectura en la percepción de lo entrevistado y su proceso de enseñanza puede instigar a la reflexión sobre la naturaleza de la danza y su intención artística. También creemos que la atención prestada a la enseñanza en el estudiante, puede ser una indicación del éxito de la compañía tanto a nivel nacional, como internacionalmente.

Palabras-Claves: Dança; Enseñanza; Arte. 
Pernambucano, nascido em 15 de abril de 1961 Jaime Arôxa é, sem dúvida, uma das referências na dança de salão brasileira. Reconhecido pela didática altamente lógica e sistematizada, ele refina e enriquece sua dança constantemente, tornando-a cada vez mais artística. ${ }^{1}$

Seu sucesso advém não apenas nos convites para coreografar novelas e minisséries de uma famosa rede de televisão, mas pela originalidade em mesclar passos tradicionais de gafieira com Fred Astaire e Gene Kelly.

Foi coreógrafo na peça teatral "O Baile", um dos maiores sucesso no mercado cinematográfico, dirigido por Etorre Scola; "Pérola" de Mauro Rasi e "Melodrama" de Denise Bandeira. ${ }^{2}$

Desde 1995 mostra-se pioneiro em desenvolver um trabalho voltado a reciclagem de professores de dança de salão oferecendo cursos regulares na própria escola e de formação continuada pelo país, apresentando informações e conhecimentos aos profissionais dessa área. Atualmente, possui uma Cia de Dança que recebe o seu nome, cuja participação em shows e eventos tem se ampliado significativamente nos últimos anos.

Ao longo de uma trajetória artística de muito trabalho e dedicação, multiplicou técnicas de ensino fundamentadas em uma didática preocupada em reconhecer a complexidade que envolve o universo de se ensinar a dança a dois.

Destarte, o sucesso do dançarino nos instigou a entrevistá-lo quando este visitou a cidade de Uberaba/MG no dia 21 de setembro de 2013, em ocasião do evento "Um pouco de tudo e muito de mim... Com o brilho do teu olhar".

Subsidiadas pelos aportes fenomenológicos ${ }^{3-4}$ nosso interesse na entrevista era buscar a essência da dança para Jaime Arôxa, incluída a subjetividade que a práxis supõe. Ademais, perpassou sobre como e o que ensinar aos demais sujeitos.

Conexões: revista da Faculdade de Educação Física da UNICAMP, Campinas, v. 12, n. 4, p. 97-101, out./dez. 2014. ISSN: 1983-9030 


\section{O que é dança pra você?}

É o sentido da minha própria vida né... Ela é onde eu tiro o alimento dos meus filhos, é da onde eu tiro a minha felicidade pessoal, é onde eu consigo ter os meus amigos, tive minhas mulheres, é onde esta o universo irreal que eu gosto mais de viver que o mundo real né?

A dança é um planeta irreal, a dança é a possibilidade que Deus deu pra humanidade, não só a dança, mas as artes de uma maneira em geral, de criar uma outra realidade, que ele pode pautar dentro do ideal do ser humano. Porque já que os próprios seres humanos não conseguem achar esse modelo ideal, eles sofrem cada dia mais com as sociedades que eles mesmos inventam, a dança traz uma automática, uma automática harmonia com tudo, com códigos, com chão, com a gravidade, com as estrelas, com tudo.

Você pode voar no chão, você pode fazer o que você quiser dançando entendeu?

E o ser humano explora isso de uma maneira cada vez mais evolutiva, porque uma vez que você é atacado por essa sensação de dançar, você meio que vicia sabe? E, se você for uma pessoa que tem certas revoltas, ou que tem certa discordância do mundo real e você chega a conclusão que esse mundo real você não vai conseguir mudar então você se conforma em poder criar o seu mundo irreal onde um bocado de maluco se reúne e é feliz, são felizes todos os dias em todos os bailes entendeu?

Então de fato quando os meus alunos entram na minha sala de aula, eu faço com que a dança seja um outro planeta, regido por outras leis, que são as leis naturais e as leis do bom senso, do equilíbrio, da harmonia, da fé, da fúria, do sexo, das coisas boas que a vida tem, em que a gente existe para aproveitá-las.

\section{Como ensinar a dança?}

Se doando ao objetivo de ver no aluno as coisas que você acredita como certas e comprovadas pela natureza da dança e do ser humano. 
Então, quando você sente que você precisa atendê-lo no sentido de fazer ele mudar, mesmo que ele não queira, ensinar mesmo que ele não saiba aprender, explicar mesmo que ele não consiga entender, arrumar formas, que se chama didática né?

A didática é uma maneira de tornar, de abrir um canal pro aluno, um canal mais dele do que seu. O professor quando ele põe o canal dele, atinge só alguns e não todos, então o canal do professor tem que ser o canal do aluno, ele então tem que ser um pouco enriquecido de humanidade, assim de conhecimento do ser humano, psicologia, de afeto de doação, de tolerância e ao mesmo tempo de exigência, de insistência, de persistência, de ousadia, de analogias, então, é preciso ter uma série de trunfos, porque cada aula é uma aula, cada dia o aluno chega de um jeito diferente, e nem todos querem a mesma coisa, nem todos buscam o mesmo objetivo, todos querem dançar, mas por trás disso tem uma coisa que cada um resgata né?

\section{O que ensinar na dança?}

Ensinar é equilibrar os corpos animal, espiritual e racional. Conseguir através de um código corporal, que são os movimentos, conseguir através de músicas adquirir uma expressão do corpo e não só da palavra.

É aprender a deixar que o corpo fale, a deixar que o corpo se divirta, a deixar que o corpo se quebre, se desconstrua se reconstrua, deixar que ele tenha uma vida própria, um pouco desligada da razão, para que ele possa ter a sua própria expressão né?

Não é uma expressão cultural e sim uma mistura, da cultura, da tua espiritualidade, da tua energia, junto com a tua técnica, a técnica que você escolheu aprender, a linguagem que você escolheu entre todas essas que existem.

Todas as danças você pode dançar e todas você pode fazer só mecanicamente, não é uma dança melhor que a outra, o que muda é quem ta fazendo.

\section{REFERÊNCIAS}

${ }^{1}$ CAMINADA, E. História da dança: evolução cultural. Rio de Janeiro: Sprint, 1999.

Conexões: revista da Faculdade de Educação Física da UNICAMP, Campinas, v. 12, n. 4, p. 97-101, out./dez. 2014. ISSN: 1983-9030 
${ }^{2}$ CENTRO DE DANÇA JAIME ARÔXA. Disponível em: http://www.jaimearoxasp.com.br/. Acesso em: 19 out. 2014.

${ }^{3}$ MERLEAU-PONTY, M. Fenomenologia da percepção. São Paulo: Martins Fontes, 1994.

${ }^{4}$ ALES BELLO, A. The language our living body. In: TYMIENIECKA, A. (Ed.). Analecta Husserliana: the yearbook of phenomenological research. Dordrecht: Springer, 2006.

Recebido em: 20 out. 2014 Aceito em: 20 nov. 2014 Contato: mcarbinatto@hotmail.com 